\title{
Communication Strategy for COVID-19 in Uruguay
}

https://doi.org/10.21814/uminho.ed.46.13

\section{Patricia Schroeder ${ }^{1}$ and Belén Amadeo ${ }^{2}$}

${ }^{1}$ Faculty of Communication, Center for Biomedical Sciences, Instituto de Estudios Empresariales de Montevideo, University of Montevideo, Montevideo, Uruguay;

${ }^{2}$ Faculty of Social Sciences, University of Buenos Aires, Buenos Aires, Argentina ${ }^{1}$ https://orcid.org/0000-0002-8911-7699; ${ }^{2}$ https://orcid.org/0000-0002-1190-6997 



\section{Abstract}

The whole world has used the term "the Uruguayan case" to describe the way that this country is dealing with COVID-19. By September 2020, Uruguay managed to minimise the negative effects that the pandemic has caused to other Latin American countries through very precise health and communication strategies, based on transparency and real time information. The chapter summarises the main communication decisions taken by the Uruguayan Government, and in particular by the Ministry of Public Health. It explains how it implemented its communication strategy, illustrated with references to news and communication materials that were developed. The chapter is written from the perspective of health communication, combined with application of conceptual models taken from strategic communication, political communication, and crisis management.

\section{Keywords}

strategic communication, crisis communication, government communication

\section{Introduction}

On March 2, 2020, a new administration was appointed for the office of communication and health of the Ministry of Public Health of Uruguay. The new management is led by a team of professionals, that has been partially renewed by the new administration.

This case presents interesting aspects both from the management and theoretical perspectives, because it shows the combined application of different conceptual frameworks that are generally considered separately. The new communicational approach is eminently technical and draws on a recent discipline: Health communication. Integrated with other professional perspectives, such as political communication, strategic communication, and crisis communication, it presents a novel approach to the informative and pedagogical treatment that the Uruguayan government has given to the COVID-19 pandemic.

In order to contextualise the information, some data on Uruguay's territory and population density is provided below (Figures 1 and 2). 


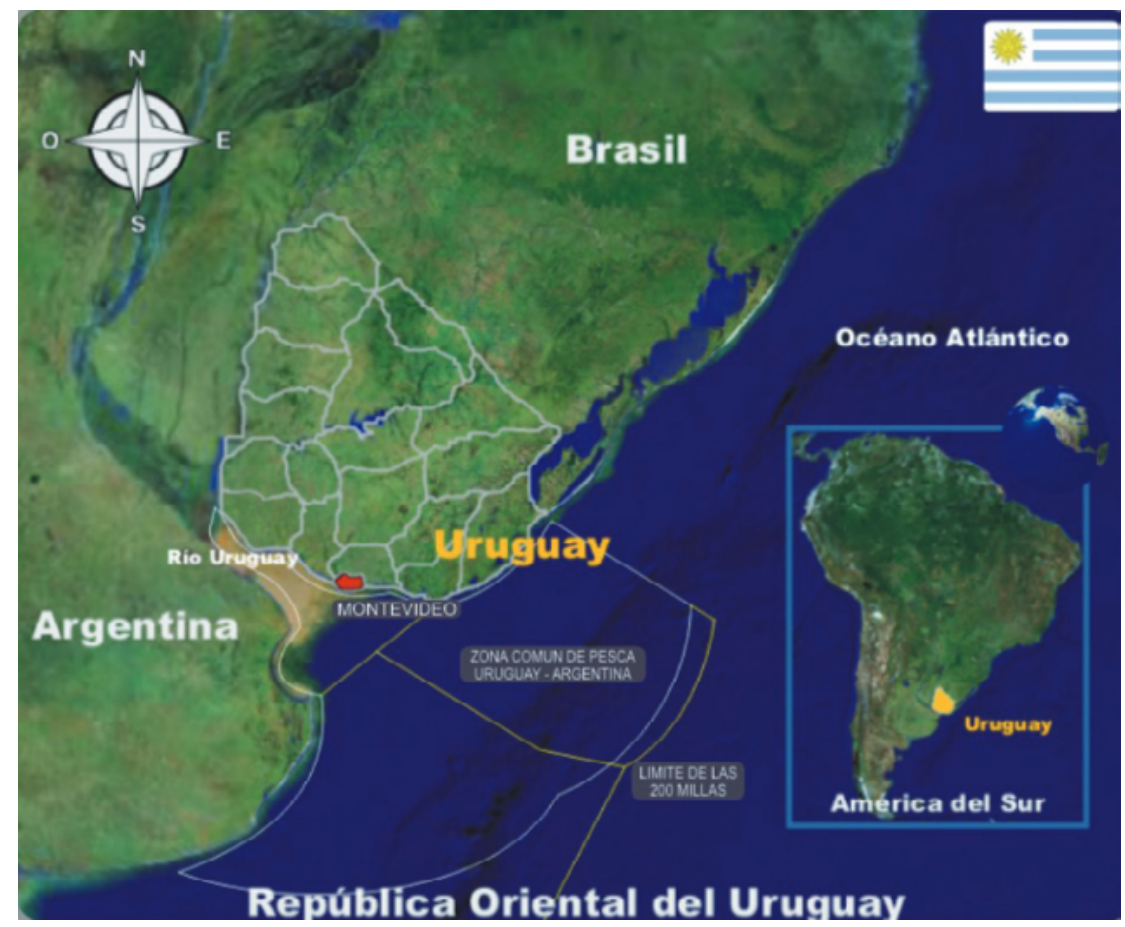

Figure 1 National territory. Total area: $176,215 \mathrm{~km}^{2}$.

Source. From Uruguay en Cifras 2014 (p. 13), by Instituto Nacional de Estadística Uruguay, 2014.

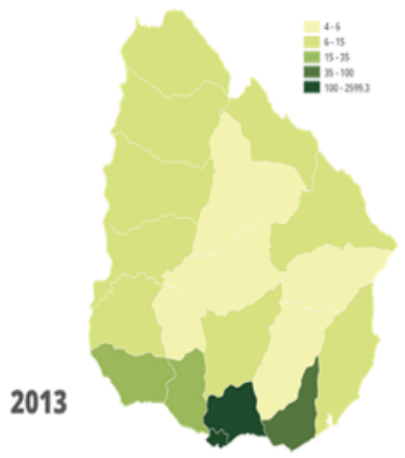

Figure 2 Total population (per 100,000 inhabitants). Total population: 3,440,157.

Source. From Uruguay en Cifras 2014 (p. 17), by Instituto Nacional de Estadística Uruguay, 2014. 


\section{The Starting Point: A Race Against Time}

The new national government took office on Sunday, March 1 (Figure 4). The public health minister and his team took office in a ceremony held on March 2 , at noon. A meeting was convened with all the actors of the health system the following morning, in order to analyse the situation of the COVID-19 pandemic in the world and its potential repercussions in Uruguay. Early in the afternoon on the same day, March 3, the notification of the first case was received in Argentina, a neighbouring country that has a very intense relationship with Uruguay. The pandemic was very close, which required an immediate and transparent statement from the new government (Ministerio de Salud Pública, 2020a; MSP - Uruguay, 2020a).

That afternoon, and transmitted by all the television channels, the population was notified about the first positive case in the neighbouring country and the government explained that Uruguay was prepared to carry out diagnostic tests locally.

Based on that press release, public opinion and journalists raised numerous questions about the Uruguayan health system. The questions focused on how many intensive care unit beds were available, whether it was possible to increase them, if there was capacity to purchase ventilators and monitors for critical patients, if there were sufficient flu vaccine doses available, if there was capacity to manage contingency hospitals, the real capacity for testing, and the diagnostic methodology, among others.

This first announcement generated a state of alert in the population, greater anxiety for information and a race against time in decision-making processes. In this context, it was decided that government communication should develop real-time response mechanisms, giving certainty to society in a time of crisis and uncertainty. In the face of an unknown enemy, it was necessary to report what could really be verified in those circumstances. Less than 24 hours after taking office, the Ministry of Public Health faced an unprecedented communication challenge.

From the perspective of communication management, there was a need to design a communication strategy with a team that was just getting to know each other, who had no experience in using their own official channels (website and social networks) and also didn't have time to establish a professional relationship with journalists, that is vitally necessary to forge bonds of trust. In this context, the response through official 
networks involved risks, but was finally considered to be the most appropriate and efficient way to build consensus amongst strategic audiences.

The general reaction was positive. The first statement and the speed of the response were taken as a sign of transparency and the intention to report in real time what a few days later became the fight against a virus, a type of pandemic that, according to the history of medicine, occurs once every 100 years.

The days that followed, from March 3 to 13 , were focused on getting to know the characteristics of the virus, how it spreads, the recommendations of the Pan American Health Organization (PAHO) and the World Health Organization (WHO) and sharing that information with the main actors of the system. Among other aspects, brochures and posters were designed and made available to the population (Ministerio de Salud Pública, 2020b, 2020g, 2020h).

On March 10, the Ministry of Public Health and its technical team held a first briefing with journalists to share the technical vision of the pandemic. This action was framed against the context of the WHO's recommendations to maintain a close link with the press and provide relevant information, so that they may be aware of the virus and the disease. A few weeks later, a second briefing was held with two scientific advisers to the minister, and later there was a third briefing to share good practices in the treatment of news related to COVID-19.

A crisis committee was constituted during the 1st week of government, comprised by expert scientists who would advise the minister of public health and recommend the measures to be taken. This independent non-partisan group of experts began to gain relevance as an "external safeguard" that validated government decisions and was held in great respect by the population. Over the ensuing weeks, the group of experts expanded through the inclusion of over 50 doctors and experts in different areas and became known as the Honorary Scientific Advisory Group (GACH). This group still advises the president of the republic on the evolution of the pandemic and makes recommendations on the conditions in which social, cultural, and economic activities in the country should be resumed.

In the early afternoon of March 13, the first four positive cases in Uruguay were confirmed, which increased the immediate demand for a nationwide campaign that would inform people about the symptoms of the disease 
and the way that it spreads in the clearest possible manner. This campaign also consisted of the creation of a website containing all the relevant information and new means of contact to serve the population, including a call centre with the capacity to handle 3,000 calls per hour. Between March 12 and 13, proposals were received from three advertising agencies in response to the public tender.

March 13 was a new milestone in the communication of COVID-19. The signing of the sanitary emergency decree introduced a package of measures that, over time, proved to be effective in controlling the spread of the virus. Performances, public gatherings, and classes at all levels were suspended. Shopping centres were also closed, and the national borders were partially closed.

On the same day, the Ministry of Public Health developed new communication channels in conjunction with the Electronic Government and Information and Knowledge Society Agency (Agesic):

- a chatbot was activated on all government websites;

- Facebook Messenger;

- free call centre with the capacity to answer 3,000 inquiries per hour (this was possible thanks to collaboration with the state-owned telephone company Administración Nacional de Telecomunicaciones [Antel]);

- a landing page with all available information on COVID-19;

- a dashboard with information on infected, recovered and deceased patients;

- a mobile app that, in its latest version, has an alert system which notifies users if they have been in contact with a person who has tested positive for COVID-19.

These new communication channels also required coordination of specialists in different areas: communication professionals, software developers, and medical professionals to review content and provide training.

Crisis communication tests the communication policy in general, the analysis of audiences, the increase in communication channels, and an adjustment in the frequency of information. The first decision is to take the initiative and become a source of information as soon as possible (de la Cierva, 2010). 


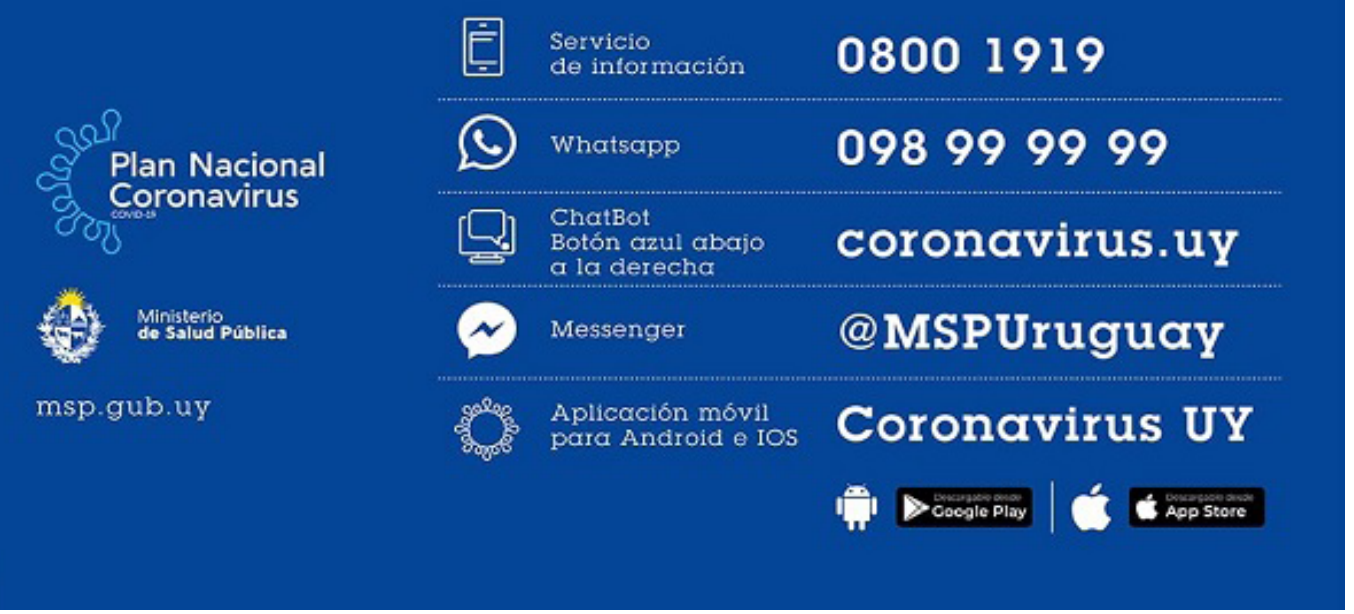

Figure 3 Communication channels developed for COVID-19.

Source. From Compartimos las vías de comunicación para responder dudas sobre el \#Coronavirus \#COVID-19, by MSP - Uruguay [@MSPUruguay], 2020b, Twitter.

The development of new channels and the consolidation of official channels constituted a clear crisis communication strategy, implemented for correct management of the pandemic. Figure 3 shows the development of new communication channels that became active in the first days of government.

Unlike other countries, where a coercive policy was implemented, in Uruguay a recommendation was made to the population not to leave their homes and a call was made for "responsible freedom", appealing to the solidarity of the population (Uruguay Presidencia, 2020b; "Quiénes Son y Cómo Trabajan los Expertos que Asesoran al Gobierno", 2020). During 1 month, the movement of people notably decreased and there was a high level of compliance. 


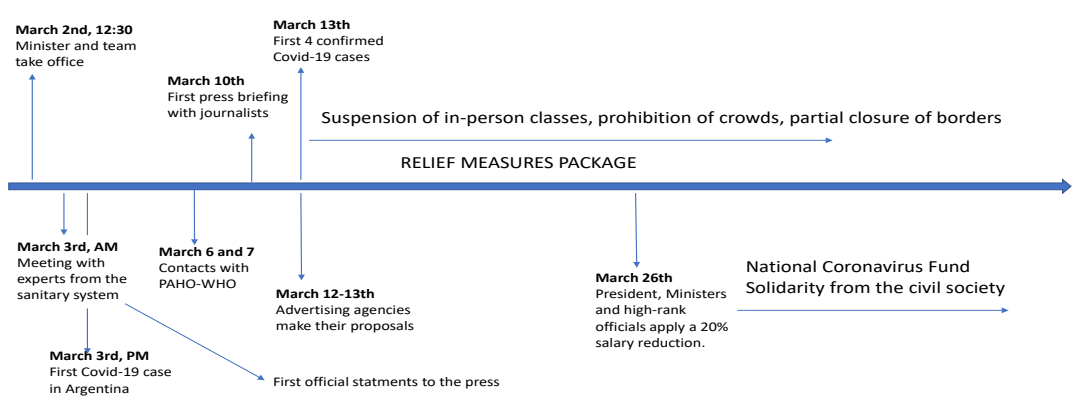

Figure 4 Timeline: 1 st month of government.

\section{March 6 and 7: Contacts with PAHO-WHO agencies}

On March 27, at the end of the 1st month of government, President Luis Lacalle Pou sought to put his own personal mark on his mandate and announced that all public officials who earned above a certain salary level would incur a $20 \%$ salary cut, in order to contribute to a fund that would be used for the extraordinary expenses caused by the pandemic. The National Coronavirus Fund was thereby created, which received donations from public and private organisations (Uruguay Presidencia, 2020c).

This government measure was exemplary and generated a strong wave of solidarity from the general public. On that date, the two advertising agencies that had been hired (Notable Publicidad and Cardinal) decided to donate their work, which included implementation of the campaign and the creative idea for the national coronavirus plan.

\section{Strategic Communication Applied to the COVID-19 Campaign}

\section{Principles of Health Strategic Communication}

We are facing an unprecedented communication situation, the number of issuers and messages about COVID-19 is such that the WHO has defined it as an "infodemic" (Organizácion Panamericana de la Salud, 2020). 
An infodemic is an excessive amount of information about a problem, that makes it difficult to find a solution. During a health emergency, infodemics can spread errors, misinformation, and rumours. They can also hamper an effective response and create confusion and mistrust in people regarding solutions or advice to prevent the disease (Organizácion Panamericana de la Salud, 2020).

The latter aspect is what renders communication about COVID-19 more complex. The scientific sphere and countries' health authorities have learned a lot about this disease since it appeared in January 2020. However, this constitutes a relatively short period of time for science to have irrefutable certainties regarding its diagnosis, treatment, and recovery. Scientific materials that help people understand the behaviour and treatment of the virus are published every day. Nonetheless, there is a permanent sense of uncertainty.

Another unprecedented aspect of this virus is its high level of contagiousness and rapid spread throughout the world. This has had a radical impact on the mobility of people and has caused a global economic crisis that also generates anxiety in the population.

COVID-19 affects all aspects of life. Countries have experienced situations of greater or lesser social isolation according to the measures introduced by their respective governments. As a result of the pandemic, deep-rooted customs and everyday gestures, such as handshaking or gestures of affection, such as hugs, are now discouraged, because they are possible routes of contagion.

In view of the above, the communication strategies related to this pandemic must address a variety of topics that consider health, in its biological, mental, social, emotional, and spiritual aspects. It must also consider all sectors of the population, broken down by age groups, communities, and population groups, according to their health conditions (patients at higher risk, persons with disabilities and their families, among others).

This is all contemplated in the strategic communication model proposed by WHO, that considers six basic principles for communication (Figure 5). 


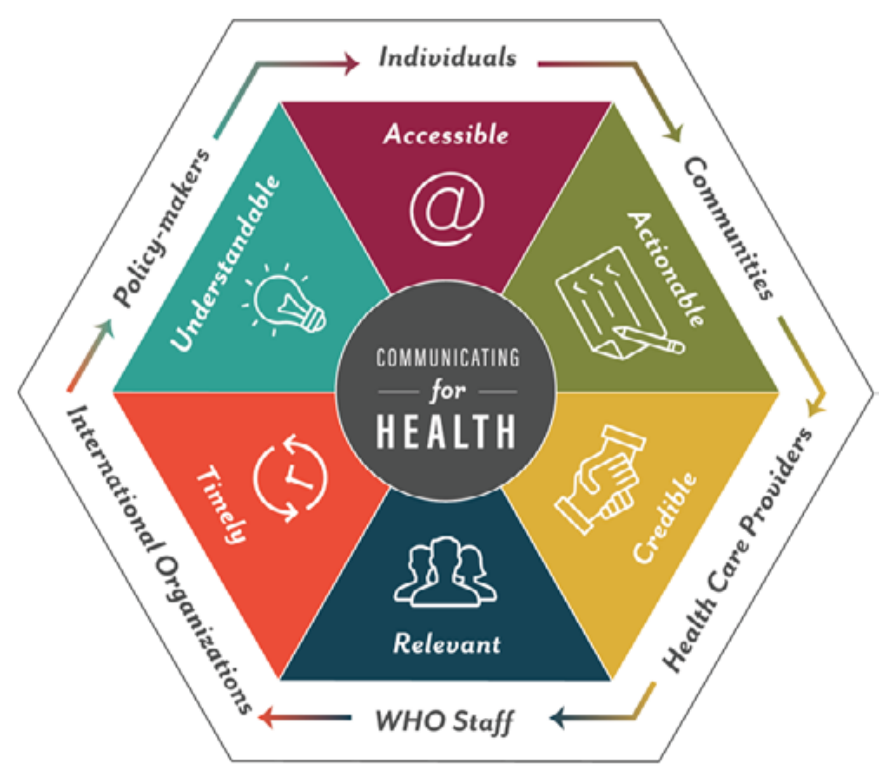

Figure 5 Principles of strategic communication, according to the WHO.

Source. From WHO Strategic Communications Framework for Effective Communications (p. 3), by World Health Organization, 2017.

The framework of each of the principles identified in Figure 5 is explained in Table 1.

Table 1 Framework of the communication principles of the World Health Organization. Source. World Health Organization, 2017.

Accessible

Actionable

Credible

Relevant

Timely

Understandable
Analysis of communication channels suitable for each audience

Study of the action and execution capacities of each of the communication proposals defined in the plan.

Refers to the trust given to the WHO and other health authorities involved in executing the communication strategy.

Linked to the audience expectations: It has to be relevant to the needs of the recipient.

Messages must be timely because they are closely linked to the specific needs of the recipient.

Refers to the content of the message, health issues must be understandable to the general public. Messages should not be addressed to expert groups. 
The identification of these communication principles proposed by the WHO are remarkable because they apply to all campaigns and all health actions and come after years of communication work in the health industry.

According to the WHO model, the effort to define the general parameters of strategic communication of the sector also defines its audiences (Table 2).

Table 2 Audiences defined by the World Health Organization.

Source. World Health Organization, 2017.

$\begin{array}{ll}\text { Individuals } & \begin{array}{l}\text { First recipients of messages and personal decision makers with collec- } \\ \text { tive impact. } \\ \text { Communities }\end{array} \\ \begin{array}{l}\text { Social groups that are part of the cultural changes necessary to increase } \\ \text { health levels. }\end{array} \\ \text { Assistance teams } & \text { Responsible for the implementation of actions. } \\ \text { Decision makers } & \text { Political actors who must define and implement health policies. } \\ \text { WHO staff } & \text { Involved in the design, implementation and evolution of campaigns. } \\ \text { International organisations } & \text { Those who intervene in the diagnosis, research and other stages of the } \\ & \text { communication process. }\end{array}$

The Uruguayan communication campaign was developed after taking these principles into consideration and was disseminated using a multi-media and multiplatform system that was first supported by two items, for radio and television, with wide coverage. The first item highlighted three symptoms of COVID-19 and the second identified seven actions to prevent it from spreading ${ }^{1}$.

The content of the items was based on the set of general recommendations issued by the WHO, the PAHO, and the experts who advise the Ministry of Public Health. The recommendation to wear face masks generated a specific point of discussion: it was made public after further investigation of experiences in other countries despite the fact that, until that moment, the indication countered the recommendation made by the international organisation.

This is only one example of the type of communication challenges faced by the health authority: it must determine a way forward; it must be certain and

\footnotetext{
${ }_{1}$ All communication materials for audiovisual channels can be found on the Ministry of Public Health's YouTube channel. https://www.youtube.com/channel/UCQWe5fq1_Q5DY92xf4aWQDW_
} 
promote a change in the habits of the population. The recommendation to wear face masks was made on April 23, but a percentage of the population had already begun to do so (Ministerio de Salud Pública, 2020i; Ministerio de Salud Pública- Uruguay, 2020a, 2020b; MSP - Uruguay, 2020c, 2020d).

Although the total numbers may be limited, Uruguayan parameters of the media dissemination of both items of communication showed that it was very extensive and covered all the country's television channels and radio stations (Tables 3 and 4).

Table 3 Campaign coverage in the initial phase (seven actions to take care of yourself and three COVID-19 symptoms).

Source. Presidencia de la República Oriental del Uruguay (internal information).

\section{Communication channel}

TV Montevideo/C4/10,12, Televisión Nacional de Uruguay, TV Ciudad, VTV, Red TV, Nuevo Siglo TV

Radio (Montevideo)

Radio (Interior - rest of the country)

Total mentions

\section{Coverage}

891

3,024

3,248

7,163

Table 4 Campaign coverage in the initial phase (protocol for entering and leaving home, communication channels, care for the elderly).

Source. Presidencia de la República Oriental del Uruguay (internal information).

$\begin{array}{lcc}\text { Communication channel } & \begin{array}{c}13 \text { to } 19 \\ \text { (March) }\end{array} & \begin{array}{c}20 \text { to } 26 \\ \text { (March) }\end{array} \\ \begin{array}{l}\text { TV Montevideo/C4/10, 12, Televisión Nacional de Uruguay, TV Ciudad, } \\ \text { VTV, Red TV, Nuevo Siglo TV }\end{array} & 662 & 743 \\ \text { Radio (Montevideo) } & 2,322 & 2,487 \\ \text { Radio (Interior - rest of the country) } & 2,800 & 2,760 \\ \text { Total mentions } & 5,784 & 5,990\end{array}$

\section{Communication Goals for COVID-19}

The main communication goal in the health area is to improve the health of individuals and social groups. In this sense, it is pertinent to remember the importance of the development of the health communication area from the 1990 s to this date. 
In the academic sphere, the Emerson University School of Communication, together with the Tufts School of Medicine define this discipline in their study programme as:

the art and technique of informing, influencing and motivating individuals, institutions and the general public on important health topics. Among those topics are disease prevention, health promotion, health policies, financing and the improvement of the quality of life and the health of community members. (Alcalay, 1999, p. 192)

The COVID-19 pandemic raises several specific secondary communication goals:

- reporting the symptoms of a disease that was unknown to this date;

- inducing new habits to prevent spreading the virus;

- make the routes of contagion known, as well as its associated risks;

- providing recommendations on what to do if a person has symptoms or has contracted COVID-19;

- providing information to key sectors of the health system: healthcare teams.

\section{Target Audiences}

In a first phase the advertisements had to reach the population as a whole and in a second phase it was necessary to address specific relevant audiences that required a custom communication adapted to their circumstances. From this segmentation, the following groups are highlighted.

People at higher risk of contracting the virus. Adults over 65 years of age, patients with type 1 diabetes, respiratory failure, other sensitive pathologies, and immunosuppressed patients were identified as population at risk and were immediately exempted from physically attending their workplace. This measure helped protect those who could contract the virus with more critical consequences.

Recommendations on the best way to stay at home, how to stay physically active, and how to take proper care of themselves were disseminated for this group. Sensitive aspects, such as elder abuse, were also addressed 
(Ministerio de Salud Pública, 2020d, 2020e; Ministerio de Salud Pública Uruguay, 2020c).

People with disabilities. In the first instance, special attention was paid to children with social and intellectual disabilities (children with Down syndrome and children with autism spectrum disorders). Secondly, efforts were placed on reaching the deaf or hearing-impaired population, and in a third phase, items were prepared with recommendations for all disability groups (Ministerio de Salud Pública, 2020c).

The material was made available through the official sites of the Ministry of Public Health with the exception of the material translated in sign language and the recommendations for people over 65 years of age. These communication items were distributed though all television channels.

Journalists. The definition of the target audiences also took into consideration the need to inform journalists about the pandemic and all medical aspects related to the virus: symptoms, diagnosis, treatment, and routes of infection. For this, two briefings were held: one by the highest-ranking authorities, at the Ministry of Public Health, and another in the executive tower, home of the presidency, by doctors specialising in the subject and members of the expert committee (Uruguay Presidencia, 2020a). There was also a third remote briefing held by the public health department to discuss with journalists how to treat COVID-19 at the informational level and what personal care measures should be taken by media workers when covering news stories. This last aspect was presented by a doctor, an occupational health specialist who works for the Ministry of Public Health (MSP - Uruguay, 2020e).

Youth. Another aspect considered was that the information should reach young people, between 15 and 25 years old. They had to receive information through specific channels and with an adapted language. To achieve this, a group of 30 influencers was contacted in social networks to develop a campaign for this audience, through two specific channels: TikTok and Instagram. The use of TikTok was an innovation for the Ministry of Public Health, which had never carried out a campaign of this nature before.

Healthcare workers. Finally, communication also had to have a chapter especially dedicated to healthcare workers at all levels. The Ministry of Public Health made an important effort to keep health institutions informed through official channels of the National Board of Health. This information 
was transmitted simultaneously through social networks so that it had a greater reach for both healthcare workers and the general public.

The Ministry of Public Health also established a training plan for nurses, which reached 485 nursing assistants and graduates (Ministerio de Salud Pública, 2020f). Additionally, a video was made to thank healthcare workers for their commitment (Ministerio de Salud Pública Uruguay, 2020d).

\section{The Style of Government Communication}

\section{Transparency as a Communication Principle}

Even before the inauguration on March 1, 2020, of President-Elect Luis Lacalle Pou, he had already declared on multiple occasions that he viewed management transparency as a fundamental value. His government's communication was developed on the basis of that value, with the aim of generating trust amongst Uruguayans.

From the first day of the new administration, the Ministry of Public Health carried out its communication with this premise as its guiding principle. WHO's communication principles were applied to content developed for all communication channels. In this sense, when transmitting the information, each item of communication should reflect the following characteristics:

- Clarity. There could be no doubts about the concepts related to COVID-19.

- Simplicity. All contents had to be understandable for the entire population.

- Didactic. Communication had to give place to a change in habits.

- Certainty. Institutional certainty had to convey security and serenity.

\section{The Content of Messages}

A few days after the start of the new administration, the national coronavirus plan, with its own logo, was created (Figures 7 and 8). The ministry had to reassure people that all communication was aligned with an action plan that was beginning to be implemented. With the same goal, a landing page was designed, which consolidated the relevant information and made 
it easily accessible. The concept of a national plan was designed with the purpose of providing certainty that a comprehensive and multidisciplinary approach was being carried out.

The creation of a national storyline implies a systemic analysis, where actions, messages, and symbols make up a comprehensive communication strategy (Figure 6). To analyse this aspect, the EVAS (context, version, action and symbols) matrix, proposed by Luciano Elizalde (2017), is used.

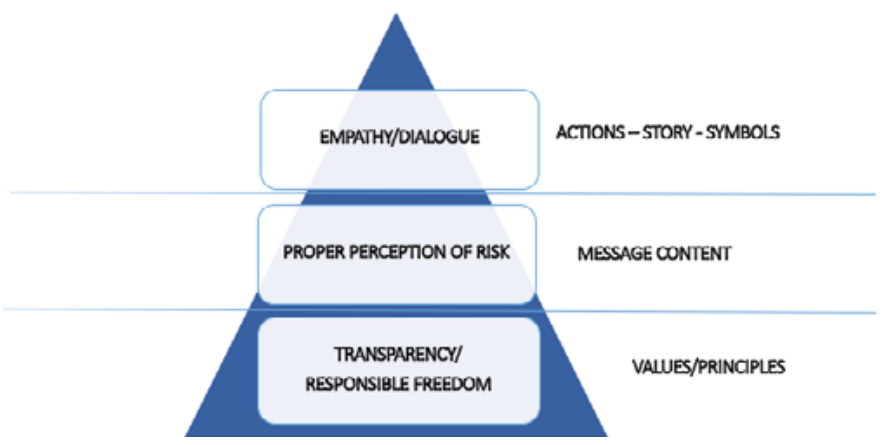

Figure 6 Communication model for construction of the storyline.

Context. The communicational context in which the topic takes place. In the case of COVID-19 this is particularly relevant because the whole world is analysing the pandemic from all possible perspectives. The virus has affected all aspects of our lives: personal relationships, the way we greet each other, the way we study, work, and even celebrate a birthday or say goodbye to a loved one at a funeral. Everything is permeated by COVID-19. It is a context with very high levels of conversation, with innumerable messages and enunciators.

Approach. This aspect refers to the general strategy to be implemented. In Uruguay, the strategy was based on the values of transparency and responsible freedom. During the first 30 days of the pandemic, the population was urged to stay at home. This was not enforced coercively. Instead, citizens were asked to stay at home and essential services were maintained. There was an announcement of the intention to keep the main driving forces of the economy active. 

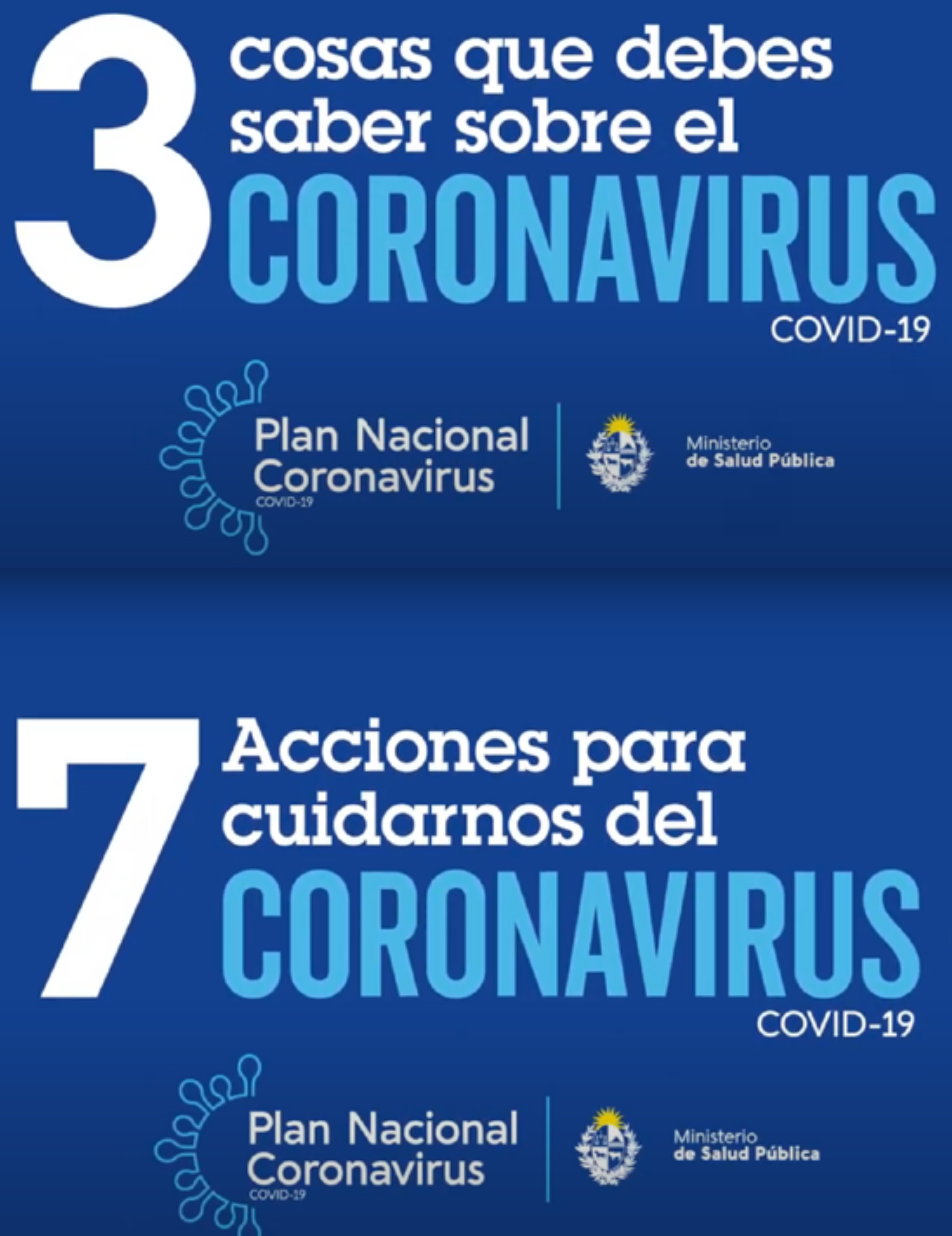

Ministerio

de Salud Pública

Figura 7 National coronavirus plan I.

Source. From MSP Síntomas (00:00:03), by Ministerio de Salud Pública Uruguay, 2020b, YouTube.

Figura 8 National coronavirus plan II.

Source. From MSP Coronavirus (00:00:09), by Ministerio de Salud Pública Uruguay, 2020a, YouTube. 
Version. This element is the strategy put into practice through a discourse, the choice of the right words. At this level, the goal was to give simple messages that were understood by the entire population.

Symbols. These details have a strong impact on communication and are represented in concrete and material aspects. In the communication of the new government, the national symbols were recovered and, although this seems an aspect that exceeds the COVID-19 communication strategy, there was an appeal to the patriotic sentiment that Uruguay is a small country that achieves unexpected results. This aspect was consolidated over the following weeks, when it was possible to observe success in the health strategy that maintains low death rates and a low level of contagion. There was worldwide recognition in international media and resulted in a positive reputation for "the Uruguayan case".

Actions. The actions that strengthen this institutional message are specified in the presence of high authorities in different parts of the country, for example, the presence of the president and the minister of public health at the border and in places that became high-risk sources. These actions in the territory gave strong support to health policy.

From the perspective of risk communication, a specific bibliography on COVID-19 communication (Moreno \& Peres, 2020) highlights several aspects that contribute to successful communication:

- The source responsible for the transmission of information must have credibility. In the case of Uruguay, the most important announcements were made by the president of the republic, the secretary of the presidency and the minister of public health. All three have high acceptance in public opinion.

- Honesty. What is not known must be clearly reported and clarified.

- Meaningful actions that help to understand the message. In Uruguay, the use of a face mask has been installed as a protection measure along with hand washing and social distancing of $2 \mathrm{~m}$. In this regard, the example set by political leaders was very important.

- Participation of experts regarding medical issues and risk communication. In Uruguay, the work of an honorary scientific advisory group made 
up of more than 50 professionals stands out. In addition, intense work has been carried out in the professionalisation of communication.

- Consistency in messages. The credibility and the change in behaviour of the population is given on a non-contradictory basis. It is necessary to show a coherent story, without second versions, where it is possible to correct mistakes because messages are being issued in a context of scientific uncertainty.

\section{Transversal Health Communication}

The COVID-19 crisis leaves important lessons, one of them is the realisation of how sensitive health is for every activity in a country, continent, and the entire world. The pandemic has forced everybody around the world to minimise all social, economic, cultural, educational, or other types of activity. People have only been able to resume these activities under certain conditions that guarantee the health of the population.

In Uruguay, several sectors of the economy and education were gradually reopened, and the consequences of greater mobility were measured. Communication played an important role in that process. Activity can be resumed only with fulfilment of certain conditions, that are stipulated in protocols.

The 4 weeks in which activity was kept to a minimum and mobility was reduced to $30 \%$ were key for the population to become aware, adjust to a change in habits and incorporate the responsibility of caring for themselves and caring for others. As mentioned above, the goal of the communication was to communicate risk adequately and, above all, induce changes in daily habits.

Communication in the initial information and prevention phase of a health policy is relevant, but it is also relevant during the subsequent stages (Figure 9). 


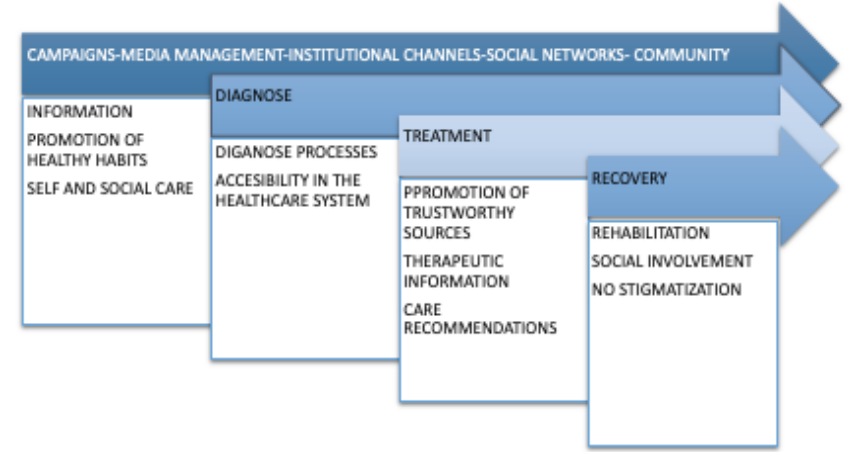

Figure 9 Transversality of communication in a health policy.

\section{Prevention Phase}

During the first stage, information about COVID-19 was transmitted, including its symptoms, forms of infection, and how to take preventive measures. At this stage, it was important to build trust and credibility to ensure a quick response from the population. Mass outreach campaigns (on traditional and social media) were important but not sufficient. As explained above, it was necessary to reach all segments of society and pay special attention to the most vulnerable. COVID-19 has the characteristic of being a pandemic that lasted over time and this aspect implies an important communication challenge.

At this stage, where the response of the population must be achieved quickly, real-time messages on the health status and the veracity of the information played an important role in Uruguay. The presence of the president of the republic, the secretary of the presidency and the ministers of state at press conferences also played a fundamental role.

\section{Diagnostic Phase}

Communication in this phase focused, firstly, on explaining the surveillance strategy and secondly on case testing. A testing methodology was established exclusively by the polymerase chain reaction (PCR) test, with monitoring of the epidemiological contacts and isolation of positive and potential patients. This work method was installed from the beginning, however, in the first weeks the test was carried out with an epidemiological 
criterion and afterwards (from April 2) a clinical criterion was established. It was important to inform the population how and under what circumstances the diagnoses were made, to bring certainties, reassurance and, at the same time, promote behaviours that help contain the virus. People considered "potential cases" after being in contact with a positive case or having symptoms, remained isolated until their diagnoses had been confirmed. For people to adopt this behaviour, it was necessary to report risks and benefits.

\section{Treatment Phase}

The treatment of the disease depends on the severity of the symptoms, which can range from a cold and muscle pain to lack of oxygen, requiring mechanical ventilation. The health system was prepared to attend the most serious cases and the number of beds in intensive care units increased by more than $30 \%$. The need to lower the risk of collapse of intensive care units was also foreseen, avoiding other acute respiratory infections. In this sense, the H1N1 flu vaccination campaign played a fundamental role, reducing serious respiratory infections and reducing deaths caused by this.

There were some debates going on about the efficacy of alternative treatments with hydroxychloroquine or chlorine dioxide, but since there is insufficient scientific evidence, the ministry of public health did not recommend them. Due to the fact that the fatality and mortality rate in Uruguay has been very low, the discussion about the treatment did not have great importance.

\section{Recovery Phase}

We can consider that the recovery phase at the social level consists of the opening of social activities with "protocols" that seek to minimise contagion. At this stage it is necessary to maintain the level of awareness of the ongoing risk of spread. To date (mid-September 2020), the pandemic has not been overcome and therefore we must prepare for the stage of recovery of what has been called a "new normal". A social and work life with behaviours that limit interactions and promote a sustained physical distancing of $2 \mathrm{~m}$.

Communication cuts across all phases of a health policy and is a key factor for its success. In the case of COVID-19, it seeks to minimise the negative effects of the pandemic and maintain the country's economic activity to the greatest possible extent.

The following figure (Figure 10) shows the main measures adopted in the different phases of the pandemic. 


\section{POLÍTICA SANITARIA COVID-19}

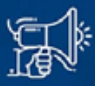

\section{PROMOCIÓN /} INFORMACIÓN

- Informe diario por canales oficiales: MSP/SINAE

- Campaña Plan Coronavirus

- Campaña Vacunación

- Gestión de prensa

- Vocería

- Capacitación periodistas

- Relación con la comunidad

- Monitoreo opinión pública - Coordinación Nacional

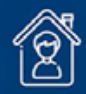

PREVENCIÓN

- Declaración de Emergencia Sanitaria

- Asegurar acceso a la Salud

- Proteger al personal de

Salud (normas y equipos)

- Distanciamiento social y

físico

- Cierre de fronteras a tiempo

- Vacunación por etapas

- Uso de tapabocas

- Prevención de efectos psicosociales

- Mapa sanitario

- Capacitación personal asistencial

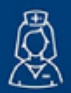

\section{DIAGNóSTICO}

- Equipo de expertos

- Test diagnóstico

- Producción nacional de

kits-importación

- Actuación de oficio en

instituciones vulnerables

(residenciales, cárceles,

asentamientos)

- Inclusión del test en el PIAS

- Atención prioritaria por gravedad

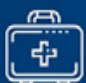

TRATAMIENTO

- Tratamiento de sostén

- Equipamiento CTI

- Equipamiento médico

- Banco de plasma

- Medicación

- Complementación

público-privada

- Complementación

público-público

- Ayuda humanitaria

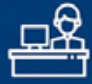

RECUPERACIÓN / REINTRODUCCIÓN

- Centros de Contingencia y Convalescencia

- Protocolos para escuelas, oficinas públicas y construcción.

- La nueva normalidad. Abordaje multidisciplinar plano socialeconómico-epidemiológico

- Acceso a la salud en nivel primario-secundario y terciario

- Organización de repatriados y corredores sanitarios

Figure 10 COVID-19 health policy.

Source. From En el marco de la \#transparencia y con el objetivo primordial de poner en conocimiento a la población en general, by MSP - Uruguay [@MSPUruguay], 2020f, Twitter.

\section{Management of Transmedia Communication}

The current complexity of the media system requires government communication offices to work on different platforms and adapt the message to the communication styles appropriate for each platform (Figure 11). 


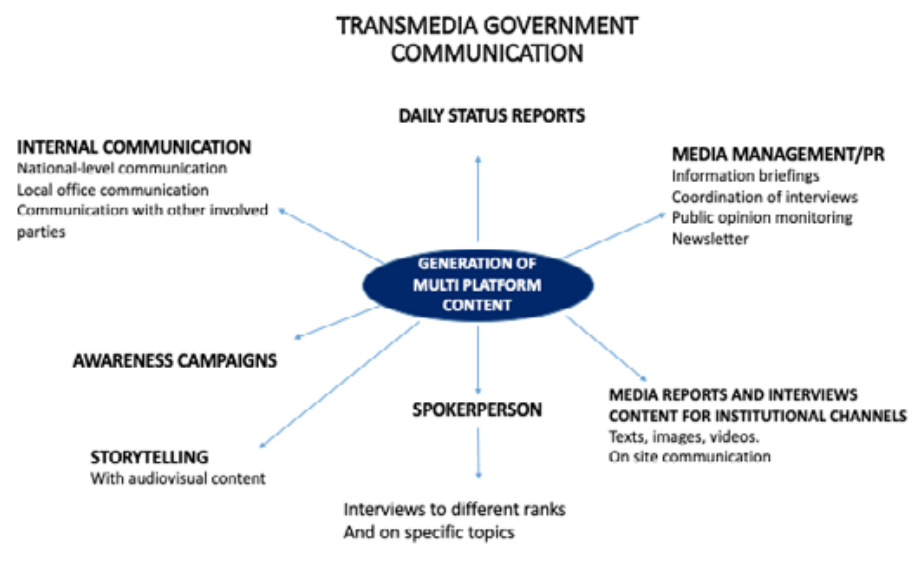

Figure 11 Generation of transmedia contents.

Nowadays, social media and traditional media coexist in a very complex media system, traditional media also have their own social network channels, journalists broadcast news on their own networks, opinion leaders have their audiences on social media and all actors coexist in a media system that has the following characteristics:

- The media system currently has the potential to provide high visibility, and this visibility empowers whoever receives it. Hence, visibility makes it possible to influence different groups of people, set up debates on the public agenda, and obtain resources for specific actions, among other benefits.

- This visibility is also two-fold. While it empowers, it also creates a risk of exposure that sometimes works against the institution's goals. It can also potentially harm people's privacy. The fine line that divides the public from the private spheres is often moved in detriment of the latter.

- We are facing an era of information overload: multiple messages that reach us through an infinity of channels (WhatsApp, email, Messenger, private messages on social networks, websites, etc.). 
- It is a closed system: the information enters the media system and it is no longer possible to "recover" it and return it to the private sphere.

- The dynamics of this system are defined by a "blind logic", it is not possible to predict the path that an event can follow when it becomes news.

- The system is governed by a principle of ubiquity: all issues related to people's lives can become a news item.

- The system also thrives on a principle of interdependence: social actors are part of this media system in a double role. On the one hand they are consumers of information and on the other they are potential sources of information.

A government communication plan is developed on the basis of this conceptual approach, seeking to generate content in all information channels and with content adapted to the logic of each channel. Communication channels complement each other, since they develop different aspects of the same institutional message.

\section{Spokesperson}

As an example, some campaigns carried out within the framework of the COVID-19 communication strategy can be mentioned, such as the vaccination campaign and the campaign for the Noche de la nostalgia (night of nostalgia) ${ }^{2}$. In both campaigns, communication pieces developed were advertised both in traditional and social media and, at the same time, were accompanied by news articles in the media, training of spokespeople, generation of news contents, press releases and an appropriate internal communication plan.

\section{References}

Alcalay, R. (1999). La comunicación para la salud como disciplina en las universidades estadounidenses. Revista Panamericana de Salud Pública, 5(3), 192-196. https://doi.org/10.1590/ S1020-49891999000300020

\footnotetext{
${ }^{2}$ On August 24, the night before Independence Day, a national holiday, it is traditional to organise parties where the protagonists are hits from other decades, oldies. Parties are organised for all ages throughout the country. Due to the pandemic a campaign was carried out to prevent the organisation of clandestine parties that could generate COVID-19 outbreaks.
} 
de la Cierva, Y. (2010). La comincación en tempos de crisis. In J. M. Mora (Ed.), 10 ensayos de comunicación institucional (pp.161-190). Eunsa.

Elizalde, L. (2017). Manejando el disenso. Estrategias, tácticas y modelos de gestión. La Crujía.

Instituto Nacional de Estadística Uruguay. (2014). Uruguay en cifras 2014. https://www.ine. gub.uy/documents/10181/39317/Uruguay_en_cifras_2014.pdf/aac28208-4670-4e96-b8c1-b2abb93b5b13

Ministerio de Salud Pública. (2020a, March 4). Ministerio de Salud confirma que el país está preparado para atender posible llegada de coronavírus. https://www.gub.uy/ministerio-salud-publica/comunicacion/noticias/ministerio-salud-confirma-pais-preparado-para-atender-posible-llegada

Ministerio de Salud Pública. (2020b, March 9). Medidas de prevención y control covid-19. https:// www.gub.uy/ministerio-salud-publica/comunicacion/publicaciones/medidas-prevencion-control-covid-19

Ministerio de Salud Pública. (2020c, March 25). Tiempos de coronavirus: Desafío para las personas con trastorno del espectro autista (TEA) y sus familias. https://www.gub.uy/ministerio-salud-publica/comunicacion/noticias/tiempos-coronavirus-desafio-para-personas-trastorno-del-espectro-autista-tea

Ministerio de Salud Pública. (2020d, April 7). Recomendaciones para personas mayores frente a Covid-19. https://www.gub.uy/ministerio-salud-publica/comunicacion/publicaciones/recomendaciones-para-personas-mayores-frente-covid-19

Ministerio de Salud Pública. (2020e,April 9). Protocolo para personas en riesgo. https://www.gub. uy/ministerio-salud-publica/comunicacion/publicaciones/protocolo-para-personas-riesgo-0

Ministerio de Salud Pública. (2020f, June 2). Plan de capacitación de enfermería: Modelo a nivel regional. https://www.gub.uy/ministerio-salud-publica/comunicacion/noticias/plan-capacitacion-enfermeria-modelo-nivel-regional

Ministerio de Salud Pública. (2020g). Protocolo de entrada: Acciones frente al covid-19 (plan nacional coronavirus). https://www.gub.uy/ministerio-salud-publica/sites/ministerio-salud-publica/files/documentos/noticias/MSP_CORONAVIRUS_PROTOCOLO_ENTRADA_0.pdf

Ministerio de Salud Pública. (2020h). Protocolo de salida: Acciones frente al covid-19 (plan nacional coronavirus). https://www.gub.uy/ministerio-salud-publica/sites/ministerio-salud-publica/ files/documentos/noticias/MSP_CORONAVIRUS_PROTOCOLO_SALIDA_0.pdf

Ministerio de Salud Pública [@mspuruguay]. (2020i, April 9). ¿Cual es la importancia de usar tapabocas en el marco de la pandemia \#Covid-19? [Video]. Instagram. https://www.instagram. com/p/B-vYc37pzxd/

Ministerio de Salud Pública- Uruguay. (2020a, April 9). ¿Cual es la importancia de usar tapabocas en el marco de la pandemia \#Covid-19? [Video]. Facebook. https://www.facebook.com/ watch/?v=1596627587153623 
Ministerio de Salud Pública- Uruguay. (2020b, April 9). Recomendaciones para el uso de tapabocas [Image attached]. Facebook. https://www.facebook.com/412806438920770/ posts/1397215630479841

Ministerio de Salud Pública Uruguay. (2020a, March 14). MSP Coronavirus [Video]. YouTube. https://www.youtube.com/watch?v=mE1AOXG1VXU

Ministerio de Salud Pública Uruguay. (2020b, March 19). MSP Síntomas [Video]. YouTube. https:// www.youtube.com/watch?v=5En0qMr7Kzl

Ministerio de Salud Pública Uruguay. (2020c, April 7). Personas de riesgo [Video]. YouTube. https://www.youtube.com/watch?v=e6jvLoZXTVo

Ministerio de Salud Pública Uruguay. (2020d, April 23). ¡Gracias! [Video]. YouTube. https://www. youtube.com/watch?v=Up543iesFwQ

Moreno, A. R., \& Peres, F. (2020). Comunicación de riesgos ante el coronavirus. Boletín sobre Covid-19: Salud Pública y Epidemiología, 1(4), 7-9. http://dsp.facmed.unam.mx/wp-content/ uploads/2013/12/COVID-19-No.4-04-Comunicaci\%C3\%B3n-de-riesgos.pdf

MSP-Uruguay [@MSPUruguay]. (2020a, March 3).Comunicado a toda la población sobre coronavirus COVID-19 en relación a casos que se han presentado en la región [Image attached] [Tweet]. Twitter. https://twitter.com/MSPUruguay/status/1234964470079852545

MSP - Uruguay [@MSPUruguay]. (2020b, March 25).Compartimos las vías de comunicación para responder dudas sobre el \#Coronavirus \#COVID-19 [Image attached] [Tweet]. Twitter. https:// twitter.com/MSPUruguay/status/1242790633556848640

MSP-Uruguay [@MSPUruguay]. (2020c, April 9).¿Cual es la importancia de usar tapabocas en el marco de la pandemia \#Covid-19? [Video attached] [Tweet]. Twitter. https://twitter.com/MSPUruguay/status/1248028028199936001

MSP - Uruguay [@MSPUruguay]. (2020d, April 9).El uso del tapabocas se suma a las recomendaciones dirigidas a la prevención del contagio por \#COVID-19. [Thumbnail with link attached] [Tweet]. https://twitter.com/MSPUruguay/status/1248241706740387840

MSP-Uruguay [@MSPUruguay]. (2020e,April 29).Esta tarde se realizó la charla “Comunicación y Salud en el marco de la pandemia \#COVID-19" [Image attached] [Tweet]. Twitter. https://twitter. com/MSPUruguay/status/1255598035222122497

MSP - Uruguay [@MSPUruguay]. (2020f, May 16). En el marco de la \#transparencia y con el objetivo primordial de poner en conocimiento a la población en general [Image attached] [Tweet]. Twitter. https://twitter.com/MSPUruguay/status/1261763591893630976

Organizácion Panamericana de la Salud. (2020). Entender la infodemia y la desinformación en la lucha contra la covid-19. Departamento de Evidencia e Inteligencia Para la Acción en Salud. https://iris.paho.org/handle/10665.2/52053 
Quiénes son y cómo trabajan los expertos que asesoran al gobierno. (2020, May 21). El Observador. https://www.elobservador.com.uy/nota/el-equipo-completo-de-cientificos-que-asesoran-al-gobierno-y-como-trabajan-2020521143522

Uruguay Presidencia. (2020a, March 19). Expertos de Comité de Gestión de Crisis que asesora al gobierno dialogaron con periodistas y evacuaron dudas. https://www.presidencia.gub.uy/comunicacion/comunicacionnoticias/salud-coronavirus-expertos-comite-crisis-periodistas

Uruguay Presidencia. (2020b, March 24). Medidas del gobierno para atender la emergencia sanitaria por coronavirus (covid-19). https://presidencia.gub.uy/comunicacion/comunicacionnoticias/medidas-gobierno-sanitaria-emergencia-sanitaria-covid19

Uruguay Presidencia. (2020c, March 27). Fondo coronavirus permitirá atender necesidades sociales y económicas de la emergencia sanitária. https://www.presidencia.gub.uy/comunicacion/ comunicacionnoticias/fondo-coronavirus-conferencia

World Health Organization. (2017). WHO strategic communications framework for effective communications. https://www.who.int/mediacentre/communication-framework.pdf?ua=1 